\title{
PERANAN PAGUYUBAN TIONGHOA PURBALINGGA DALAM PELESTARIAN TRADISI CAP GO MEH
}

\section{Rina Fitriyani $\bowtie$}

SMA Hidayah Purbalingga Jawa Tengah Indonesia

\section{Info Artikel}

Sejarah Artikel:

Diterima Desember 2011

Disetujui Januari 2012

Dipublikasikan Maret 2012

\section{Keywords:}

Community;

Conservation;

Cap go meh traditio;

Tionghoa;

Purbalingga.

\begin{abstract}
Abstrak
Tujuan penelitian ini adalah menggambarkan peran Paguyuban Tionghoa Purbalingga (PTP) dalam menjaga kebudayaan Tionghoa, khususnya tradisi Cap Go Meh. Sebelum Paguyuban Tionghoa Purbalingga terbentuk, perayaan Cap Go Meh hanya dirayakan dalam lingkup keluarga dan di dalam rumah saja, akan tetapi setelah adanya Paguyuban Tionghoa Purbalingga tradisi ini dirayakan secara terbuka sehingga tidak hanya golongan Tionghoa yang merasakan akan tetapi juga masyarakat Purbalingga. Penelitian ini menggunakan pendekatan kualitatif dengan lokasi penelitian di kabupaten Purbalingga. Menggunakan bentuk analisis interaktif, penelitian ini menghasilkan fakta-fakta sebagai berikut. Bentuk-bentuk pelestarian tradisi Cap Go Meh meliputi perlindungan, pengembangan, dan pemanfaatan tradisi Cap Go Meh. Makna tradisi Cap Go Meh bagi masyarakat Tionghoa Purbalingga adalah wujud syukur, dan sarana berkumpul. Tradisi ini mengandung nilai 8 Jalan Kebenaran bagi golongan Tionghoa sesuai ajaran Tridharma Tionghoa yaitu kesetiaan (loyality), integritas (integrity), kesopanan (propriety), kebenaran moral (righteousness), kehormatan (honour), bakti (filial piety), kebajikan (kindness), kasih sayang (love).
\end{abstract}

\begin{abstract}
The objective of this study is to describe the role of Chinese Society of Purbalingga (PTP) in conserving Chinese culture, especially the tradition of Cap Go Meh. Before the establishment of the Chinese Society of Purbalingga, Cap Go Meh was celebrated only in the sphere of family and home, but after the Chinese Society of Purbalingga was established, the tradition was celebrated openly so that not only the Chinese but also people of Purbalingga can feel its presence. The study method used is qualitative approach and the research sites is in the district Purbalingga. Using the form of interactive analysis, this research found the following facts. Preservation of Cap Go Meh tradition include these practices: protection, development, and utilization of Cap Go Meh tradition. The meaning of Cap Go Meh tradition for the Chinese community in Purbalingga is an act of gratitude, and means of assembly. Besides, this tradition contains the value of 8 way sof truth according to the teachings of the Chinese Tridharma, loyality, integrity, propriety, righteousness, honor, filial piety, kindness, and love.
\end{abstract}

(C) 2012 Universitas Negeri Semarang

\footnotetext{
Alamat korespondensi:

SMA Hidayah Purbalingga Jawa Tengah Indonesia 49078

ISSN 2086-5465

E-mail: rinafitriyani@yahoo.com
} 


\section{PENDAHULUAN}

Bangsa Indonesia merupakan bangsa multikultural. Furnivall dalam Muin (2006:121) menyatakan bahwa masyarakat multikultural merupakan masyarakat yang terdiri atas dua atau lebih komunitas yang secara komunitas atau kelompok yang secara kultural dan ekonomi terpisah-pisah serta memiliki struktur kelembagaan yang berbeda-beda satu sama lainnya. Bangsa Indonesia memiliki berbagai macam agama, suku bangsa dan keturunan, baik dari keturunan Cina, India, Arab dan lain-lain. Setiap golongan memiliki karakteristik yang berbeda-beda baik dari segi bahasa, identitas kultural, maupun adat istiadatnya, tetapi terikat oleh suatu kepentingan bersama bersifat formal dalam bentuk sebuah negara.

Dari berbagai golongan yang ada di Indonesia, golongan Tionghoa merupakan salah satu golongan terbesar di Indonesia. Golongan Tionghoa seperti yang tercantum dalam penjelasan UUD 1945 disebut sebagai peranakan Tionghoa, jumlahnya diperkirakan 5\% dari penduduk Indonesia. Itu artinya sedikitnya ada 12 juta orang golongan Tionghoa di Indonesia dan tersebar hampir di seluruh kota di Indonesia.

Dalam kehidupan sehari-hari tampak bahwa kelompok minoritas berusaha menggunakan etika, pakaian, sistem budaya, serta tipikal makanan kelompok dominan. Oleh karena itu, kelompok etnis dominan juga merupakan kelompok budaya dominan. Akan tetapi dalam kehidupan intern, kelompok etnis minoritas masih menggunakan kesetiaan primordial etnis minoritas, seperti bahasa daerah, adat, dan kebiasaan lainya yang dianggap perlu untuk mempertahankan identitas etnis minoritas.

Golongan Tionghoa di kota kecil pada umumnya masih berpegang teguh pada tradisi leluhur. Theresia dan Hidayat dalam Wahyuningsih (2006) menyebutkan sekitar $80 \%$ golongan Tionghoa menggunakan tradisi leluhur dalam lingkungan kehidupan golongan Tionghoa seperti dalam upacara kematian, meminang, pertunangan, pernikahan, melahirkan, upacara tolak bala, dan masih banyak lagi upacara lainnya.
Tradisi ini masih bersifat sangat kaku terutama kalau ada orang tua yang tersisa dalam keluarga, sebab ada kepercayaan bila melanggar tradisi kelak dikemudian hari akan membawa bencana serta kesukaran hidup bagi kehidupan hidupnya ataupun keluarga.

Undang-Undang Nomor 12 Tahun 2006 tentang Kewarganegaraan Republik Indonesia yang dikeluarkan pada era reformasi ini semakin memperjelas status etnis Tionghoa dalam kebangsaan Indonesia. Lewat UU tersebut, etnis Tionghoa diakui sebagai pribadi yang berkebangsaan Indonesia tanpa memandang suku maupun etnisitasnya. Kemajemukan bangsa Indonesia dihargai dan bahkan diakui oleh pemerintah sebagai ciri yang utama. Etnis Tionghoa yang memilih untuk bergabung demi memperjuangkan kepentingan mereka pada akhirnya kembali mengaktifkan kegiatan mereka dalam organisasi Tionghoa yang telah "mati suri" akibat tekanan dari rezim orde baru.

Kebudayaan Tionghoa dapat diterima oleh masyarakat Indonesia dan mendapat penilaian positif, salah satunya adalah tradisi Cap Go Meh. Penerimaan masyarakat Purbalingga terhadap golongan Tionghoa sudah cukup baik. Hal ini dapat dilihat dalam hubungan perdagangan, belum pernah terjadi konflik antar golongan Pribumi dengan golongan Tionghoa. Golongan Tionghoa di Kabupaten Purbalingga secara umum termasuk dalam kategori kelas ekonomi menengah ke atas. Kehidupan golongan Tionghoa sangat erat dengan perdagangan. Dapat dikatakan bahwa hampir setiap toko, kios-kios, rumah makan, bengkel, dan lain-lain di sepanjang jalan utama di daerah perkotaan di Purbalingga dimiliki oleh golongan Tionghoa. Selain itu pabrikpabrik besar di Kabupaten Purbalingga pada umumnya adalah milik golongan Tionghoa, secara tidak langsung golongan Tionghoa sangat mempengaruhi perekonomian di Kabupaten Purbalingga. Masyarakat Purbalingga sudah terbiasa dengan keberadaan golongan Tionghoa, masyarakat setempat tidak merasa bermasalah meskipun perekonomian secara umum dikuasai oleh 
golongan Tionghoa dan bersifat terbuka.

Salah satubudaya Tionghoa yang masih dilestarikan oleh masyarakat Tionghoa di Purbalingga adalah tradisi Cap Go Meh yang dirayakan pada hari ke-15 setelah tahun baru Imlek. Masyarakat Tionghoa di Kabupaten Purbalingga setiap tahun merayakan tradisi Cap Go Meh dengan berbagai kegiatan. Pada tahun 2008, Paguyuban Tionghoa Purbalingga (PTP) merayakan tradisi Cap Go Meh dengan menyelenggarakan sunatan massal. Sebelum dilakukan sunatan massal, peserta diarak keliling kota Purbalingga menggunakan becak. Peserta mendapatkan bingkisan yang terdiri dari baju koko, kopiah, sarung dan uang saku. Sunatan massal berlangsung di gedung Dharma Mulya di Jalan M.T. Haryono yang merupakan tempat pertemuan Paguyuban Tionghoa Purbalingga (PTP). Bupati Purbalingga Triyono Budi Sasongko juga ikut serta dalam merayakan tradisi Cap Go Meh dan merasa bangga masyarakat Tionghoa Purbalingga mampu menggelar kegiatan berupa kepedulian sosial Sunatan Massal dengan bekerja sama dengan beberapa organisasi lainnya.

Dalam masyarakat multikultural, keanekaragaman suku bangsa, agama, serta stratifikasi sosial telah menumbuhkan kelompok-kelompok sosial ataupun lembaga-lembaga sosial yang bersumber dari kebudayaan. Pentingnya kesukubangsaan terwujud dalam bentuk kelompok-kelompok suku bangsa dan digunakan sebagai jati diri.

Paguyuban Tionghoa Purbalingga (PTP) merupakan suatu kelompok sosial atau lembaga yang dibentuk oleh masyarakat Tionghoa Purbalingga khususnya generasi mudanya. Dengan adanya Paguyuban Tionghoa Purbalingga diharapkan kebutuhan-kebutuhan masyarakat Tionghoa dapat terpenuhi. Salah satu harapan masyarakat Tionghoa adalah ingin mempertahankan jati dirinya yaitu kebudayaannya yang salah satunya adalah tradisi Cap Go Meh.

\section{METODE PENELITIAN}

Penelitian ini menggunakan me- tode kualitatif dengan pendekatan deskriptif kualitatif yang menguraikan dan menggambarkan tentang peranan Paguyuban Tionghoa Purbalingga dalam melestarikan tradisi Cap Go Meh sebagai usaha-usaha yang aktif dan berjalan terus-menerus serta bentuk-bentuk pelestarian tradisi Cap Go Meh dan nilai-nilai yang terkandung dalam perayaan tradisi Cap Go Meh di Kabupaten Purbalingga.

Lokasi dalam penelitian ini adalah di Kabupaten Purbalingga. Lokasi tersebut dipilih dengan pertimbangan berikut: Kabupaten Purbalingga merupakan kota kecil yang di dalamnya terdapat golongan minoritas yaitu golongan Tionghoa yang pada umumnya golongan Tionghoa di Purbalingga masih berpegang teguh pada tradisi leluhurnya salah satunya yaitu penyelenggaraan tradisi Cap Go Meh. Paguyuban Tionghoa Purbalingga, merupakan salah satu organisasi Tionghoa yang menyelenggarakan tradisi Cap Go Meh terdapat di Kabupaten Purbalingga.

Sesuai dengan permasalahan penelitian maka, penulis memfokuskan perhatian pada: Peranan Paguyuban Tionghoa Purbalingga dalam pelestarian tradisi Cap Go Meh yaitu sumbangan atau kontribusi yang diberikan Paguyuban Tionghoa Purbalingga (PTP) dalam pelestarian tradisi Cap Go Meh. Bentuk-bentuk pelestarian tradisi Cap Go Meh di Kabupaten Purbalingga yaitu bagaimana upaya-upaya yang dilakukan oleh Paguyuban Tionghoa Purbalingga dalam mempertahankan tradisi Cap Go Meh untuk memperkuat jati diri sebagai golongan Tionghoa yang meliputi: perlindungan tradisi Cap Go Meh, pengembangan tradisi Cap Go Meh, pemanfaatan tradisi Cap Go Meh, makna tradisi Cap Go Meh bagi masyarakat Tionghoa Purbalingga.

Subjek dalam penelitian ini adalah pengurus dan anggota Paguyuban Tionghoa Purbalingga. Peneliti memilih individu yang mengetahui secara mendalam mengenai fokus penelitian antara lain: penasehat, ketua, sekertaris dan anggota Paguyuban Tionghoa Purbalingga. Sumber data dalam penelitian ini dibedakan menjadi dua, yaitu data primer dan data sekunder. Data primer 
adalah data yang diperoleh secara langsung melalui wawancara dengan subjek dan informan. Data sekunder bersumber dari literatur yang relevan, yakni buku-buku, artikel yang berkaitan dengan permasalahan dalam penelitian ini seperti dokumen dari Paguyuban Tionghoa Purbalingga.

Teknik pengumpulan data yang dipergunakan dalam penelitian ini adalah observasi, wawancara mendalam, serta dokumentasi di mana mengambil atau mengutip dokumen yang berhubungan dengan permasalahan penelitian yaitu berupa foto-foto perayaan, film perayaan Cap Go Meh, dan profil Paguyuban Tionghoa Purbalingga sehingga data tersebut digunakan untuk mendukung kelengkapan data yang ada pada penulis.

\section{HASIL DAN PEMBAHASAN}

Pendekatan fungsionalisme-struktural dari Brown dan Malinowski (dalam Brata, 2008:154-155) mengatakan bahwa "fungsi" suatu institusi sosial ialah hubungan fungsi itu dengan kebutuhan organisasi sosial. Istilah organisme bukanlah merupakan suatu struktur, organisme adalah kumpulan unit (sel atau molekul) yang disusun dalam suatu struktur, yaitu dalam satu set hubungan. Suatu sel atau unsur mempunyai aktivitas, dan aktivitas itu mempunyai fungsi. Fungsi adalah sumbangan di mana aktivitas suatu bagian (unsur) itu berguna bagi kesluruhan unit entitas (organisme atau masyarakat). Fungsi suatu aktivitas sosial adalah sumbangan yang diberikannya kepada keseluruhan kehidupan sosial yang merupakan fungsi keseluruhan sistem sosial tersebut. Pendapat yang demikian menunujukan bahwa sistem sosial mempunyai suatu jenis kesatuan, yang disebut sebagai kesatuan fungsional. Kesatuan fungsional didefinisikan sebagai suatu keadaan di mana semua bagian di dalam sistem sosial itu bekerja dalam keadaan yang cukup harmonis.

Menurut Parsons, fungsionalismestruktural sering menggunakan konsep sistem ketika membahas struktur atau lembaga sosial. Sistem ialah organisasi dari keseluruhan bagian-bagian yang saling tergantung. Ilustrasinya bisa dilihat dari sistem listrik, sistem pernapasan, atau sistem sosial yang mengartikan bahwa fungionalisme struktural terdiri dari bagian yang sesuai, rapi, teratur, dan saling bergantung. Layaknya sebuah sistem, maka struktur yang terdapat di masyarakat akan memiliki kemungkinan untuk selalu dapat berubah. Karena sistem cenderung ke arah keseimbangan maka perubahan tersebut selalu merupakan proses yang terjadi secara perlahan hingga mencapai posisi yang seimbang dan hal itu akan terus berjalan seiring. Masyarakat sebagai suatu sistem memiliki struktur yang terdiri dari banyak lembaga, di mana masing-masing lembaga memilki fungsi sendiri-sendiri. Lembaga sosial yang berada dalam keseimbangan mempolakan kegiatan manusia berdasarkan norma-norma yang dianut bersama serta dianggap sah dan mengikat peran serta manusia itu sendiri. Lembaga-lembaga yang kompleks ini secara keseluruhan merupakan sistem sosial di mana setiap bagian (masingmasing unsur kelembagaan itu) saling tergantung dengan semua bagian yang lain, sehingga perubahan salah satu bagian akan mempengaruhi kondisi sistem keseluruhan.

Lembaga-lembaga sosial dalam masyarakat dianggap sama dengan organorgan tubuh. Lembaga-lembaga sosial sebagai unsur struktur dianggap dapat memenuhi kebutuhan kelangsungan hidup dan pemeliharaan masyarakat. Setiap lembaga mempunyai fungsinya masingmasing dan dalam hubungan antara satu dengan yang lainnya (Soekanto, 1982:6).

Menurut Parsons (Ranjabar, 2006 : 16) bahwa masing-masing subsistem dan sistem bertindak (budaya, sosial, kepribadian, dan organisme perlaku), secara fungsional dapat dianalisis sebagai "sistem gerak sosial" yang masing-masing subsistem mempunyai fungsi sebagai berikut:

Subsistem budaya/kultur (Latent patern maintenance) yaitu fungsi mempertahankan pola termasuk ke dalam kerangka hubungan antara masyarakat sebagai sistem sosial dengan subsistem budaya sebagai subsistem dari seistem gerak sosial. Suatu subsistem 
budaya memberikan jawaban terhadap masalah-masalah mengenai faktor-faktor dasar terhadap falsafah hidupnya.

Subsistem sosial (Integration) yaitu fungsi integrasi mencakup faktor-faktor yang diperlukan untuk mencapai keadaan yang serasi antar bagian suatu sistem. Subsistem kepribadian (Goal attainment) yaitu fungsi mencapai tujuan termasuk di dalam kerangka hubungan antar masyarakat atas dasar masyarakat perlu mengorganisasikan warganya untuk mencapai tujuan bersama yang biasanya dianggap sebagai aspek politik dan masyarakat. Subsistem organisasi perilaku (Adaptasi) yang mencakup pengarahan dan penyesuaian antara kebutuhan-kebutuhan pokok manusia dengan keadaan di sekeliling masyarakat.

Merton (dalam Kaplan dan Manners 2002:79) menjelaskan bahwa terdapat fungsi manifes dan fungsi laten (fungsi tampak dan fungsi terselubung) dalam suatu tindak atau unsur budaya. Fungsi manifest adalah "konsekuensi objektif yang memberikan sumbangan pada penyesuaian atau adaptasi sistem yang dikehendaki dan disadari oleh partisipan sistem tersebut". Sebaliknya fungsi laten adalah suatu ihwal budaya yang "tidak dikehendaki maupun disadari" oleh warga masyarakat.

Paguyuban Tionghoa Purbalingga (PTP) merupakan salah satu lembaga yang di dalamnya terdapat hubungan antara individu dan kelompok Tionghoa dan menciptakan harapan-harapan bagi perilaku individu khususnya golongan Tionghoa Purbalingga. Harapan-harapan ini menghasilkan peranan-peranan (role) tertentu yang harus dilaksanakan agar dapat memenuhi kebutuhan golongan Tionghoa dan tetap berkembang dalam masyarakat Kabupaten Purbalingga. Dalam Paguyuban Tionghoa Purbalingga memiliki kesatuan fungsional yang di dalamnya terdapat suatu struktur sosial. Setiap manusia dalam Paguyuban Tionghoa Purbalingga adalah unsur penting. Fungsi suatu aktivitas sosial adalah sumbangan yang diberikan Paguyuban Tionghoa Purbalingga pada masyarakat Tionghoa di Kabupaten Purbalingga.

Lembaga sosial merupakan suatu sistem yang terdiri dari komponenkomponen dalam organisasi yaitu: tujuan organisasi yaitu keadaan tertentu yang ingin dicapai oleh organisasi. Tujuan organisasi dapat menimbulkan kinerja, motivasi, kerjasama, dan komunikasi yang lebih jelas. Filosofi organisasi adalah dasar pemikiran yang digunakan dalam membentuk dan menggerakkan organisasi berupa pertimbangan-pertimbangan yang lebih terinci dan luas berkaitan dengan kewajaran perilaku, kegiatan dan fungsi-fungsi di dalam sistem yang diantaranya penjabaran tentang apa yang dianggap baik dan yang dianggap buruk oleh organisasi, yang merupakan pengorganisasian sikap-sikap spesifik ke dalam suatu struktur

Komposisi anggota yaitu proporsi anggota organisasi dilihat dari karakteristik tertentu. Struktur organisasi yaitu sesuatu yang menunjukan bagaimana organisasi itu mengalokasikan tugas, dan menunjukkan mekanisme formal koordinasi serta pola interaksi yang seharusnya dilakukan. Teknologi yaitu segala alat dan cara yang dipakai untuk mencapai tujuan organisasi.

Menurut Tonnies (dalam Soekanto, 1990:132), hubungan-hubungan positif antara manusia selalu bersifat Gemeinschaft (paguyuban) atau Gesselschaft (patembayan). Gemeinschaft (paguyuban) adalah bentuk kehidupan bersama di mana anggotaanggotanya diikat oleh hubungan batin yang murni dan bersifat alamiah serta bersifat kekal. Dasar hubungan tersebut adalah rasa cinta dan rasa kesatuan batin yang memang telah dikodratkan. Kehidupan tersebut dinamakan juga bersifat nyata dan organis, sebagaimana diumpamakan dengan organ tubuh manusia atau hewan. Sebaliknya, Gesselschaft (patembayan) merupakan ikatan lahir yang bersifat pokok untuk jangka waktu yang pendek, bersifat sebagai suatu bentuk dalam pikiran belaka serta strukturnya bersifat mekanis sebagaimana dapat diumpamakan dengan sebuah mesin.

Di Kabupaten Purbalingga terdapat komunitas etnis Tionghoa yang masih terlihat kekhasannya yaitu dalam mempertahankan kebudayaanya. Berdasarkan sejarahnya sejak abad pertama Masehi sudah terjadi kontak 
dagang antara pedagang Tionghoa dengan masyarakat lokal. Hingga pada akhir abad ke19 situasi perekonomian di Cina memburuk dan pada saat bersamaan pemerintah Hindia Belanda membuka perkebunan dan pertambangan-pertambangan baru yang memerlukan banyak tenaga kerja. Maka terjadilah migrasi besar-besaran orang Cina ke berbagai daerah di Indonesia. Hal ini dapat dilihat dari berbagai peninggalan sejarah terutama bangunan-bangunan di berbagai kota di Indonesia. Salah satunya di Purbalingga ada bangunan bersejarah tersebut yaitu Gedung Kong Kwan atau lebih dikenal sebagai Gedung Dharma Mulia.

Gedung itu pada awalnya didirikan sebagai tempat berkumpulnya orang-orang Tionghoa di Purbalingga. Dari foto dan dokumen yang ada gedung itu telah ada sejak awal tahun 1900an. Pada masa itu berdiri perkumpulan orang-orang Tionghoa Purbalingga yang disebut Tiong Hoa Hwee Kwan (THHK) pada tanggal 30 Juli 1927. Pendirian perkumpulan Tiong Hoa Hwee Kwan di Purbalingga merupakan kelanjutan dari berdirinya perkumpulan Tiong Hoa Hwee Kwan di Batavia pada tahun 17 Maret 1900 (Freddy, 1997).

Sejalan dengan tujuan utama dibentuknya Tiong Hoa Hwee Kwan maka Gedung Kong Kwan itu juga berdiri sekolah Tionghoa mulai dari tingkatan sekolah dasar hingga kelas satu sekolah menengah pertama. Tionghoa itu sempat berhenti sejak Jepang masuk ke Indonesia sekitar tahun 1942 karena pada waktu itu banyak guru yang ditangkap oleh Jepang. Setelah kemerdekaan sekolah itu kembali dimulai namun kegiatan-kegiatan perkumpulan lainnya tetap berhenti. Hingga akhirnya pada 4 Maret 1957 diadakan rapat umum anggota perkumpulan dengan agenda melakukan pergantian kepengurusan dan mengaktifkan kembali kegiatan perkumpulan. Pada tahun 1959 pemerintah Orde Lama pada saat itu mengeluarkan Peraturan Pemerintah No. 10 yang melarang WNA Tionghoa untuk melakukan perdagangan eceran di luar ibukota Provinsi dan Kabupaten. Sehingga banyak orang-orang Tionghoa yang terpaksa kembali ke Cina daratan. Untuk mensiasati dampak politik dari Peraturan Pemerintah No. 10 ini maka pada tahun 1960 nama perkumpulan Tiong Hoa Hwee Kwan diganti namanya menjadi Perkumpulan Masyarakat Purbalingga (PMP). Tujuan awal pendirian Tiong Hoa Hwee Kwan pun diubah dan dipersingkat yaitu hanya terlibat mengusahakan usaha-usaha dalam pendidikan, kebudayaan, dan kesosialan.

Menurut Jusuf (2008), semua warga negara Republik Pakyat Cina disebut bangsa Tionghoa karena dalam bahasa Mandarin disebut Cung Hua Ren Ming Kung He Kuo. Cung Hua dalam dialek Hokkian dilafalkan menjadi "Tionghoa" ; Ren Ming artinya rakyat; dan Kung He Kuo Han artinya negara republik. Maka orang Republik Rakyat Cina menyebut dirinya "Hua Ren" yang berarti bangsa Tionghoa.

Golongan Tionghoa adalah bagian dari bangsa Indonesia. Keturunan Tionghoa di Indonesia sudah menjadi Warga Negara Indonesia dan di Indonesia semua warga negara Indonesia adalah Bangsa Indonesia. Golongan Tionghoa di Indonesia merupakan bangsa Indonesia, suku bangsa Tionghoa, sub suku Hakka atau Hokkian, atau Kanton, dan lain sebagainya.

Istilah etnografi untuk suatu kebudayaan dengan corak khas adalah suku bangsa atau dalam bahasa Inggris ethnic group (kelompok etnik). Suku bangsa bersifat kesatuan "golongan" bukan sifat kesatuan "kelompok". Konsep suku bangsa lebih kompleks, karena batas dari kesatuan manusia yang merasakan diri terikat oleh keseragaman kebudayaan dapat meluas atau menyempit bergantung pada keadaan (Koentjaraningrat, 1999). Jadi masyarakat Tionghoa yang menjadi Warga Negara Indonesia, tidak lagi menyatakan lagi sebagai bangsa Tionghoa, lebih tepat sebagai Warga Negara Indonesia, suku bangsa Tionghoa. Suku bangsa Tionghoa sudah diakui sebagai salah satu suku bangsa di Indonesia.

Meskipun agama Buddha tidak asli dari Tionghoa, tetapi ajaran Buddha mempunyai pengaruh yang cukup berarti pada kehidupan golongan Tionghoa. Tema pokok ajaran Buddha adalah bagaimana menghindarkan penderitaan umat manusia 
di dunia. Sebab menurut Buddha kehidupan manusia adalah penuh penderitaan (samsara). Manusia yang lemah dan tidak berpengetahuan mudah terkena kejahatan. Padahal kejahatan adalah pangkal dari penderitaan. Upaya untuk membebaskan diri adalah melalui reinkarnasi, agar manusia dapat memperbaharui kehidupan secara lebih baik (Winarta, 2007:80).

Ajaran Tao ditulis dalam kitab Tao Teh Ching yang terdiri dari 5000 huruf. Isinya merupakan kumpulan ajaran tentang eksistensi manusia di dunia dilihat darinosisi tertentu. Ajaran ini memberikan pedoman perilaku dan moral manusia melalui rumusan-rumusan yang diungkapkan dengan mengambil analogi peristiwa-peristiwa alam.

Menurut kitab Tao Teh Ching seharusnya manusia mengikuti geraknya Tao (hukum alam), yaitu kesederhanaan hukum alam (Hariyono, 2006:187).

Ajaran Taoisme banyak mempengaruhi pola pikir orang Tionghoa mengenai hidup sederhana, Jalan Tengah (hukum keseimbangan yang mengatasi dua dikotomi yang berjauhan) dan penyesuaian diri dengan lingkungan sehingga manusia dapat hidup di mana pun manusia berada.

Konfisius adalah seorang nabi, nama keluarga Khong (Kong), sedangkan $\mathrm{Hu}$ adalah nama kebesaran yang diberikan kepadanya, dan nama pribadinya adalah $\mathrm{Cu}$ (Chiu), sehingga namanya dikenal dengan Khong $\mathrm{Hu} \mathrm{Cu}$ ataupun Kong Ciu. Dalam lafal Cina-Jawa ada yang menyebutnya Kong Co.

Pada dasarnya ajaran konfisius mengajarkan tentang moralitas yang harus dimiliki oleh setiap manusia. Konfisius ingin melanjutkan tradisi masa lampau dan menciptakan suatu tradisi yang kukuh. Konfisius beranggapan bahwa orang "liar" akan menjadi beradab apabila manusia mengikuti tradisi yang diciptakannya. Isi dari tradisi dihimpun dalam lima istilah kunci ajaran Konfisius. Masyarakat memiliki tradisi yang masih dipercaya keberadaannya, tradisi itu tidak terlepas dari bagian kebudayaan yang tumbuh dan berkembang di tengah masyarakat. Tradisi sama dengan adat-istiadat yaitu konsep serta aturan yang mantap dan terintegrasi kuat dalam sistem budaya yang menata tindakan manusia dalam kehidupan sosial budaya (Koentjaraningrat, 1984:187). Hal yang paling mendasar dari tradisi adalah adanya informasi yang diteruskan dari generasi ke generasi baik tertulis maupun (sering kali) lisan, karena tanpa adanya ini, suatu tradisi dapat punah.

Pemujaan kepada leluhur sering dikaitkan dengan festival. Pada masa kuno festival memiliki arti khusus karena dihubungkan dengan pemujaan untuk mengenang para dewa. Bagi orang Tionghoa sikap hidup kekeluargaan yang kuat dan tradisi yang mendarah daging dalam mengejar keberuntungan dan kemakmuran menjadi modal untuk bisa bertahan hidup di rantau (Nugraha, 2008:107).

Tradisi Cap Go Meh adalah salah satu wujud kebudayaan Tionghoa yang masih berkembang dan dirayakan setiap tahunnya oleh golongan Tionghoa dan biasanya melakukan pawai, arak-arakan di sepanjang jalan dan festival lampion. Hari raya Cap Go Meh atau Yuan Xiaojie dalam bahasa Tionghoa yang jatuh pada tanggal 15 bulan pertama tahun Imlek adalah salah satu hari raya tradisional Tiongkok. Menurut tradisi rakyat Tiongkok, sehabis Cap Go Meh, maka berakhirlah seluruh perayaan Tahun Baru Imlek. Malam Cap Go Meh adalah malam pertama bulan purnama setiap tahun baru. Pada malam itu, rakyat Tiongkok mempunyai kebiasaan memasang lampion berwarna-warni, maka festival ini juga disebut sebagai "hari raya lampion".

Pelestarian Kebudayaan Tionghoa yang dilestarikan adalah eksistensi kebudayaan Tionghoa. Dengan demikian upaya pelestarian menjadi suatu usaha yang dinamis. Dalam pengertian pelestarian tercakup tiga rincian tindakan yaitu: perlindungan, pengembangan dan pemanfaatan (Chollin, 2008).

Perlindungan kebudayaan merupakan segalaupayapencegahandanpenanggulangan gejala yang dapat menimbulkan kerusakan, kerugian atau kemusnahan bagi manfaat dan keutuhan sistem gagasan, sistem perilaku, dan atau benda budaya akibat 
perbuatan manusia ataupun proses alam. Termasuk kedalam upaya perlindungan ini adalah perlindungan terhadap kerusakan/ kepunahan dan perlindungan terhadap penggunaan yang tidak patut, tidak adil, atau tanpa hak, pengembangan kebudayaan adalah upaya perluasan dan pendalaman perwujudan budaya, serta peningkatan mutu dengan memanfaatkan berbagai sumber dan potensi, pemanfaatan kebudayaan adalah upaya penggunaan perwujudan budaya untuk kepentingan pendidikan, agama, ekonomi, dan ilmu pengetahuan.

Salah satu tujuan Paguyuban Tionghoa Purbalingga adalah pelestarian kebudayaan Tionghoa sebagai identitas masyarakat Tionghoa. Paguyuban Tionghoa Purbalingga mempunyai peran melestarikan tradisi kebudayaan Tionghoa, salah satu upayanya adalah pelestarian tradisi Cap Go Meh dengan merayakannyan setiap tahun. Dalam perayaan Paguyuban Tionghoa Purbalingga sebagai perencana, persiapan dan pelaksana sehingga perayaan dapatberjalan. Tradisi Cap Go Meh perlu dipertahankan keberadaannya sebagai identitas diri dari suatu kebudayaan Tionghoa dan mempunyai makna bagi masyarakat Tionghoa Purbalingga.

\section{SIMPULAN}

Paguyuban Tionghoa Purbalingga terbentuk berdasarkan keturunan yang sama yaitu golongan Tionghoa. Fungsi Paguyuban Tionghoa Purbalingga sesuai dengan visi misinya yaitu mengumpulkan anak-anak muda Tionghoa Purbalingga untuk menata kembali organisasi Tionghoa dan misi mempererat tali persaudaraan dan komunikasi antar etnis Tionghoa Purbalingga terutama generasi mudanya, serta lebih mengenalkan nilai-nilai luhur budaya Tionghoa pada generasi muda. Salah satu upaya yang sudah di laksanakan adalah dengan merayakan kembali tradisi Cap Go Meh dengan penuh makna dan kebersamaan.

Upaya Paguyuban Tionghoa Purbalingga dalam melindungi tradisi Tionghoa khususnya tradisi Cap Go Meh Paguyuban Tionghoa Purbalingga dengan mengenalkan budaya Tionghoa yang di dalamnya terdapat materi mengenai tradisi-tradisi Tionghoa salah satunya Tradisi Cap Go Meh dan nilai-nilai budaya Tionghoa dengan membuat Buletin Dharma Mulia dan membuat website Paguyuban Tionghoa Purbalingga yang dapat dilihat oleh masyarakat secara umum. Paguyuban Tionghoa Purbalingga juga mempunyai program Personal data base adalah pengumpulan data orang-orang Tionghoa Purbalingga untuk membangun rasa kebersamaan dan persatuan yang erat.

Perayaan Cap Go Meh juga dimanfaatkan Paguyuban Tionghoa Purbalingga sebagai sarana silaturahmi dan menjalin kebersamaan antar golongan Tionghoa dan masyarakat Purbalingga secara umum. Tradisi Cap Go Meh merupakan festival atau puncak perayaan Imlek yang didalamnya terdapat nilai kekeluargaan, kebersamaan, dan harapan untuk menjadi manusia yang lebih baik. Yang paling penting dalam perayaan Cap Go Meh adalah adanya kebersamaan selain itu juga membagi kebahagiaan dengan orang lain. Sesuai dengan 8 Kebajikan atau Jalan Kebenaran golongan Tionghoa yang ada dalam perayaan tradisi Cap Go Meh yaitu kesetiaan (loyality), integritas (integrity), kesopanan (propriety), kebenaran moral (righteousness), kehormatan (honour), bakti (filial piety), kebajikan (kindness) dan kasih sayang (love).

Hendaknya Paguyuban Tionghoa Purbalingga tetap menjaga eksistensinya dalam upaya melestarikan kebudayaan Tionghoa, hendaknya Masyarakat Tionghoa lebih memahami eksistensi kebudayaan Tionghoa dan dapat mengetahui perkembangan kebudayaan Tionghoa di Kabupaten Purbalingga. Pemerintah daerah diharapkan untuk berusaha mengoptimalkan potensi-potensi budaya yang ada dan diharapkan akan terwujud adanya suatu kerjasama dalam usaha pelestarian kebudayaan.

\section{DAFTAR PUSTAKA}

Brata, N.T. 2008. PT. Freeport Dan Tanah Adat Kamoro Kajian Teori-Teori Antropologi. Semarang: 
UNNES PRESS.

Chollin. 2008. Pentingnya Pelestarian Kebudayaan. http//www.forumbudaya.org. yang diakses pada tanggal 19 April 2009.

Freddy, S. 2007. Sejarah Yang Hampir terlupakan Dinamika Kehidupan Masyarakat Tionghoa Purbalingga.Buletin Dharma Mulia Media Informasi dan Komunikasi Masyarakat Tionghoa Purbalingga. Edisi 1- Juli 2007 . hlm. 6-8

Hariyono, P. 2006. Menggali Latar Belakang Streotip Dan Persoalan Etnis Cina Di Jawa, Dari Jaman Kekemasan, Konflik Antar Etnis Hingga Kini. Semarang: Mutiara Wacana.

Jusuf, I. 2008. WNI Suku Bangsa Tionghoa. http// debian.petra.journalis.ac.id.

Kaplan, D. dan R.A. Manners. 2003. Teori Budaya. Yogyakarta: Pustaka Pelajar.

Koentjaraningrat. 1999. Manusia dan Kebudayaan di Indonesia. Jakarta: Djambatan.

Listiyani, T. 2011. Partisipasi Masyarakat Sekitar Dalam Ritual di Kelenteng Ban Eng Bio Kecamatan Adiwerna. Jurnal Komunitas. 3 (1):
$1-8$

Miles, M.B. dan A.M. Huberman. 1992. Analisis Data Kualitatif. Jakarta: UI Press.

Muin, I. 2006. Sosiologi SMA Jilid 2. Jakarta: Penerbit Erlangga.

Nugraha, A. 2008. Membaca kepribadian Orang-Orang China. Jogjakarta : Garasi.

Ranjabar, J. 2006. Sistem Sosial Budaya Indonesia (Suatu Pengantar). Bogor: Penerbit Ghalia Indonesia.

Ritzer, G. 2004. Teori sosiologi Modern. Jakarta: Prenada Media.

Soekanto, S. 1982. Teori Sosiologi Tentang Pribadi Masyarakat. Jakarta: Ghalia Indonesia.

Wahyuningsih, D. 2006. Relasi Sosial Antara Etnik Tionghoa Dan Etnik Jawa (Studi Kasus Siswa SMA $N$ I Purbalingga). Skripsi. Semarang: Fakultas Ilmu Sosial.

Winarta, F.H. 2007. Globalisasi Dan Sikap Organisasi Tionghoa. Dalam http://www.media perhimpunan INTI Suara Baru Edisi 14/III/ Maret 200725. yang diakses pada tanggal 19 April 2009. 